this part of the work are parasites, and this extends the sphere of its usefulness beyond the confines of academic zoology into the realms of applied biology and medicine. Thus, a considerable body of recent research claims a place in a work of this type. A survey of the lists of references is reassuring. For example, of the 169 references on the Hemosporidia, 82 are dated from 1940 onwards. However, the authors have not yielded to the temptation to weight the volume unduly on the applied side of the subject. The chapter on malaria, for example, is concise and, although it contains a modicum of information on anti-malarial drugs and on the vectors and their control, it does not disrupt the balance and continuity of the zoological approach.

In general, the treatment of the various groups is well balanced, half of the volume being devoted to the Rhizopoda and Actinopoda, and the remaining half to the Sporozoa and Cnidosporidia. A chapter on the cytology of the Acantharia and Radiolaria is presented as an addendum. It calls on recent results of work by A. Hollande and M. Enjumet to provide a means of supplementing the treatment of problematic questions concerning the interpretation of cell structures and life-cycles in these two groups. This is just one of the examples of the care with which the authors are attempting to minimize the risk of early obsolescence which so often detracts from the value of works of this nature and scope. Style and presentation are lucid throughout, and should not present any undue difficulty to the English-speaking reader. Zoologists the world over owe a great debt of gratitude to their French colleagues for a truly indispensable book.

OTTO LOWENSTEIN

\section{THE COUNTRY NATURALIST}

Birds of the Field

By James Fisher.

Butterflies of the Wood

By S. and E. M. Beaufoy.

Flowers of the Wood

By F. M. Day,

Birds of Town and Village

By R. S. R. Fitter.

(The Country Naturalist Books.) Pp. $36+32$ plates each vol. (London: William Collins, Sons and Co., Ltd.) 3s. 6d. net each.

$\mathrm{M}$ ESSRS. COLLINS, whose "New Naturalist" series of books made a special niche for themselves both in book production and in the literature of natural history, are now issuing a new series under the general title "The Country Naturalist", which one presumes can be looked upon as a shortened and cheaper form of the "New Naturalist".

James Fisher, one of the editors of the "New Naturalist" series, is the editor of this new series, so both lay and professional naturalists can rest assured that the new venture is being well looked after and that the best possible author for each topic will be selected.

The objective of these new books is to present a well-illustrated and popular introduction of each topic to non-professional readers; though it is difficult to imagine the informed field naturalist and certainly the biologist not finding much of value and interest in each book.
The method of approach is ideal for the readers whom the editor has in mind. As he points out in his introduction, Great Britain, with its varied geology and climate, presents an intricate patchwork of woods, fields, moors, mountains, towns and rivers, with a margin of sea-coast of comparatively great length and complexity. Since each of these types of country supports its own peculiar communities of plants and animals, the obvious way to approach the study of our flora and fauna (especially from the initial point of view of identification) is through these divisions ; though no doubt the various authors will realize that there is much overlapping in Nature and therefore will not confine themselves too rigidly to organisms specially adapted to, and therefore found exclusively in, the selected area. Judging from the first four books, there is to be no risk of this.

James Fisher starts the series himself with "Birds of the Field". He begins by explaining his method of selection with which no one can disagree, and then he plunges straight into his descriptions of birds to be found, classifying them in their accepted families such as those of the crow, starling, weaver, etc.fourteen in all. The text is just what one has learned to expect from Fisher's pen-descriptions by a wellknown expert and well-trained observational ornithologist who fortunately has the rare gift of analysis and interpretation which the untrained mind can not only grasp but also finds fascinating. All the thirtytwo full-page plates are photographs, mostly illustrating one species in its natural surroundings, occasionally two. Sixteen are delightful colourphotographs. All the photographs have been taken. by well-known colour-photographers.

S. and E. M. Beaufoy were a good choice for "Butterflies of the Wood". Their method of approach is similar to that of Fisher's. Again there are thirtytwo plates of illustrations ; but here it is possible to present twenty colour-photographs and eighty-one photographs in black-and-white.

F. M. Day's "Flowers of the Wood" is in the same vein, though here the introduction is longer, taking the form of an excellent essay on British woods. Well-known flower photographers have contributed seventeen colour- and nineteen black-and-white photographs which make up the thirty-two plates.

Finally, none other than R. S. R. Fitter, who charmed thousands of readers with his "London's Natural History" and also wrote the "Pocket Guide to British Birds", has contributed "Birds of Town and Village" to the series. His methods of dealing with his topic are similar to those of Fisher and the result is equally as good. His text is illuminated by thirty-two plates carrying twenty colour- and twentytwo black-and-white photographs.

In none of these books is the text confused with unnecessary technical terms or scientific names. In each case, however, a classified list of scientific names, following the most recently accepted rules for zoological and botanical nomenclature, is appended.

We note that among other books in preparation are "Flowers of the Seaside" by Ian Hepburn and "Birds of the Seaside" by James Fisher, and many more are on the way. This is good news, because here is an excellent series. James Fisher the editor, all the authors, and Collins the publishers are not only to be congratulated but also thanked for making available to everybody such books of convenient pocket size and at a price that anyone can afford. L. J. F. BRtmble 